\title{
NOTES
}

\section{AN UNKNOWN "WASHINGTON LETTER" BY WALT WHITMAN}

Between 1863 and 1865, Whitman published a number of articles in The New York Times, in the form of "Washington Letters." All have been identified and reprinted, with a single exception, the one presented here, which appeared in the issue for 12 March 1865, p. 5, cols. 1-2.

When he collected the material for Memoranda During the War (1875-76), Whitman included the "Washington Letters," but only after he had revised them and added new subtitles. Whitman then revised the Memoranda versions for publication in Specimen Days. Unfortunately, Floyd Stovall, the editor of Prose Works 1892 (New York: New York University Press, 1963), was not aware of the article of 12 March 1865 , and added an erroneous note - "Not previously published"-to the four extracts from it that appear in Memoranda and Specimen Days: "The Inauguration," "The Weather-Does It Sympathize with These Times?," "Inauguration Ball," and "Scene at the Capitol" (see Stovall, 1:92, 94-95, 95, 95-96). Seventy-eight lines of the original text have therefore never before been noted.

Here, then, is the complete article, apparently Whitman's last war-time letter to The New York Times, exactly as he wrote it, before it was revised and shortened. It is more spontaneous - and, it might be argued, more effective-than the extracts that appeared in Memoranda and Specimen Days. It might be noted, too, that it appeared only five weeks before his "Captain" was felled by an assassin's bullet. This fact adds to the pathos of Whitman's familiar description of Lincoln in the inaugural procession to and from the Capitol: Lincoln is alone in his carriage, "very much worn and tired; the lines, indeed, of vast responsibilities, intricate questions, and demands of life and death, cut deeper than ever upon his dark brown face." It is almost as if Whitman can sense the impending assassination; he notes the aberrant and violent weather that "sympathizes with the times," and the "curious little white cloud" that "appeared like a hovering bird" directly over Lincoln. And Whitman notes how vulnerable the President is, riding in "his plain two-horse barouche," his young son at his side, accompanied only by civilians on horseback; absent are the military guards that had always accompanied him during the war.

One fascinating section that Whitman did not reprint in Memoranda or Specimen Days consists of a catalogue of Pennsylvania Avenue on that muddy Inauguration Day: the "Maternal" Capitol ("with milky bulging dome") hovers over all, and freed black soldiers, "with raised faces, well worth looking at themselves, as new styles of physiognomical pitures," pause and join others looking up at the Western star, "quite plain just after midday." 


\title{
NEWS FROM WASHINGTON.
}

\author{
The Last Hours at Congress - Washington Crowds, \\ and the President.
}

From an Occasional Correspondent. WASHington, Monday, March 6, 1865.

The just closed hours of the Nineteenth Presidentiad, and of the Thirty-Eighth Congress of the Nation, afford two or three items, merging into the inauguration of the Twentieth, which you will probably not receive by telegraph, but may be worth while for me to catch as they are flying, and jot them down. So I will skip what is latest up this morning-SHERIDAN's reported victory over EARLY, the pending Departmental and other nominations, \&c., (the forthcoming Ball in the Patent Office also,) and write my passing observations of last Saturday. Simply saying, first, however, that I have this moment been up to look at the gorgeously arrayed ball and supper-rooms, for the Inauguration Dance aforesaid, (which begins in a few hours;) and I could not help thinking of the scene those rooms, where the music will sound and the dancers' feet presently tread-what a different scene they presented to my view a while since, filled with a crowded mass of the worst wounded of the war, brought in from Second Bull Run, Antietam, and Fredericksburgh. Tonight, beautiful, women, perfumes, the violins' sweetness, the polka and the waltz; but then, the amputation, the blue face, the groan, the glassy eye of the dying, the clotted rag, the odor of old wounds and blood, and many a mother's son amid strangers, passing away untended there, (for the crowd of the badly hurt was great, and much for nurse to do, and much for surgeon.) Think not of such grim things, gloved ladies, as you bow to your partners, and the figures of the dance this night are loudly called, or you may drop on the floor that has known what this one knew, but two short winters since.

\section{INCIDENT AT THE CAPITOL.}

To begin with the morning of Saturday last. The day just dawned, but in halfdarkness, every thing dim, leaden, and soaking. In that dim light of dawn, under such circumstances, a strange occurrence happened in the Capitol, in the Hall of the House. The members were nervous, from long drawn duty, exhausted, some asleep, and many half asleep. The gas-light, mixed with dingy day-break, produced an unearthly effect. The poor little sleepy, stumbling pages, the smell of the Hall, the members with heads leaning on their desks asleep, the sounds of the voices speaking, with unusual intonations, the general moral atmosphere also of the close of this important session, the grandeur of the Hall itself, with its effect of vast shadows up toward the panels and spaces over the galleries, all made a marked combination. In the midst of this, with the suddenness of a thunderbolt, burst one of the most angry and crashing storms of rain and wind ever heard. It beat like a deluge on the heavy glass roof of the hall, and the wind literally howled and roared. For a moment, (and no wonder) the nervous and sleeping Representatives were thrown into confusion. The slumberers waked with fear, some started for the doors, some looked up with blanched cheeks and lips to the roof, and the little pages began to cry; it was a scene. But it was over almost as soon as the drowsied men were actually awake. They recov- 
ered themselves; the storm raged on, beating, dashing, and with loud noises at times. But the House went ahead with its business then, I think, as calmly and with as much deliberation as at any time in its career. Perhaps the shock did it good. (One is not without an impression, after all, amid these members of Congress, of both the Houses, that if the flat and selfish routine of their duties should ever be broken in upon by some great emergency involving real danger, and calling for first class personal qualities, those qualities would be found generally forthcoming and from men not now credited with them.)

\section{PENNSYLVANIA AVENUE.}

As the day advanced, of course Pennsylvania avenue absorbed all. The show here was to me worth all the rest. The effect was heterogeneous, novel, and quite inspiriting. It will perhaps be got at, by making a list in the following manner, to wit: Mud, (and such mud!) amid and upon which streaming crowds of citizens; lots of blue-dressed soldiers; any quantity of male and female Africans, (especially female;) horrid perpetual entanglements at the crossings, sometimes a dead lock; more mud, the wide street black, and several inches deep with it; clattering groups of cavalrymen out there on a gallop, (and occasionally a single horseman might have been seen, \&c;) processions of firemen, with their engines, evidently from the north; a regiment of blacks, in full uniform, with guns on their shoulders; the splendor overhead; the oceanic crowd, equal almost to Broadway; the wide Avenue, its vista very fine, down at one end closed by the capitol, with milky bulging dome, and the Maternal Figure over all, (with the sword by her side and the sun glittering on her helmeted head;) at the other, the western end, the pillared front of the Treasury Building, looking south; altogether quite a refreshing spot and hour, and plenty of architectural show with life and magnetism also. Among other times, our heavenly neighbor Hesperus, the star of the West, was quite plain just after midday; it was right over head. I occasionally stopped with the crowd and looked up at it. Every corner had its little squad, thus engaged; often soldiers, often black, with raised faces, well worth looking at themselves, as new styles of physiognomical pictures.

\section{THE PROCESSION AND THE PRESIDENT.}

In some respects the printed reports of Saturday's ceremonies here will give you a widely erroneous notion of the way they really transpired. For instance, the different parts of the procession were characterized by a charming looseness and independence. Each went up and down the Avenue in the way and at the time which seemed convenient, and was a law unto itself. The President very quietly rode down to the capitol in his own carriage, by himself, on a sharp trot, about noon, either because he wished to be on hand to sign bills, \&c., or to get rid of marching in line with the muslin Temple of Liberty, and the pasteboard Monitor. I saw him on his return, at three o'clock, after the performance was over. He was in his plain two-horse barouche, and looked very much worn and tired; the lines, indeed, of vast responsibilities, intricate questions, and demands of life and death, cut deeper than ever upon his dark brown face; yet all the old goodness, tenderness, sadness, and canny shrewdness, underneath the furrows. (I never see that man without feeling that he is one to become personally attached to, for his combination of purest, heartiest tenderness, 
and native Western even rudest forms of manliness.) By his side sat his little boy, of ten years. There were no soldiers, only a lot of civilians on horseback, with huge yellow scarfs over their shoulders, riding around the carriage. At the inauguration four years ago, he rode down and back again surrounded by a dense mass of armed cavalrymen eight deep, with drawn sabres, and carbines clanking at their sides, and there were sharp-shooters stationed at every corner on the route.

I ought to mention the President's closing Levee of Saturday night last. Never before was such a compact jam in front of the White House, all the grounds filled, and away out to the spacious sidewalks. But I forego that reception, and finish off with something I have on my mind about no more uncommon topic than simply the Weather. It refers to the hours and events immediately upon us, so is fit for a newspaper.

\section{DO THE HEAVENS SYMPATHIZE WITH US?}

Whether the rains, and the heat and cold, or what underlies them all, are affected with what affects man in masses, and follow his play of passionate action, strained stronger than usual, and on a larger scale than usual; - whether this, or no, it is certain that there is now, and has been for twenty months or more on this American Continent North, many a remarkable, many an unprecedented expression of the subtle world of air above us and around us. There, since this war, and the wide and deep national agitation, strange analogies. Different combinations, a different sunlight or absence of it, different products even out of the ground. After every great battle, a great storm. Even civic events, the same. On Saturday, a forenoon like whirling demons, dark, with slanting rain, full of rage; and then the afternoon, so calm, so bathed with flooding splendor from heaven's most excellent sun, with atmosphere of sweetness; so clear it showed the stars, long, long before they were due. As the President came out on the capitol portico, a curious little white cloud, the only one in that part of the sky, appeared like a hovering bird, right over him.

Indeed, the heavens, the elements, all the meteorolgical [sic] influences, have run riot for weeks past. Such caprices, abruptest alternations of frowns and beauty, I never knew. It is a common remark that (as last Summer was different in its spells of intense heat from any preceding it) the Winter just completed has been without parallel. It has remained so down to the hour I am writing. Much of the daytime of the past month was sulky, with leaden heaviness, fog, interstices of bitter cold, and some insane storms. But there have been samples of another description. Nor earth, nor land ever knew spectacles of superber beauty than some of the nights have lately been here. The Western Star, in the earlier hours of evening, has never been so large, so clear; it seems as if it told something, as if it held rapport indulgent with humanity, with us Americans. Five or six nights since, it hung close by the moon, then a little past its first quarter. The star was wonderful, the moon like a young mother. The sky, dark blue, the transparent night, the planets, the moderate west wind, the elastic temperature, the unsurpassable miracle of that great star, and the young and swelling moon swimming in the west, suffused the soul. Then I heard, slow and clear, the deliberate notes of a bugle come up out of the slience [sic], sounding so good through the night's mystery, no hurry, but firm and faithful, floating along, rising, falling leisurely, with here and there a long-drawn note; the bugle, well played, sounding tattoo, in one of the army hospitals near here, where the wounded (some of them per- 
sonally so dear to me) are lying in their cots, and many a sick boy, come down to the war from Ohio, Illinois, Wisconsin, and the rest.

WALT WhitMan.

\title{
"I'LL TRACE THIS GARDEN": A NOTE ON A NON-WHITMAN AT- TRIBUTION
}

There is little basis for a Whitman attribution that appears in the "Uncollected Manuscript Fragments" section of Leaves of Grass, Comprehensive Reader's Edition, ed. Harold W. Blodgett and Sculley Bradley (New York: New York University Press, 1965). pp. 697-698. The holograph poem, in the Feinberg-Whitman Collection, Library of Congress Manuscript Division, reads:

\author{
[I'll Trace This Garden] \\ 1
}

I'll trace this garden oer \& oer

Meditate on each sweet flower

Thinking of each happy hour

$$
2
$$

Some say my love is gone to France

3

I'll sell my frock - I'll sell my where ${ }^{1}$

4

I wish I was on yonder hill

It's there I'd sit \& cry my fill

So every tear should turn a mill

5

I'll dye my dress - I'll dye it red

Over the world I'll beg my bread

My parents dear shall think me dead

This undated, untitled, and unsigned poem was written in black ink on the letterhead of the Attorney General's Office, Washington, D.C., where Whitman served from 1 July 1865 to 1873 , when he suffered a stroke and a year later left government service. The poem is written without revision in a clear, even hand, and is unlike anything Whitman ever wrote for Leaves of Grass, with its syrupy subject matter, child-like rhyme scheme, and absence of any terminal punctuation.

Fortunately, another poem survives that Whitman had written out during this period on the blank side of another Attorney General's Office letterhead, and this apparently clears up the mystery of how the "Garden" poem came to be in Whitman's hand. Whitman had written out Emerson's poem "Brahma" without title or author's name in black ink, in a clear, even hand. (Whether he wrote out both poems around the same time cannot be determined.) The "Brahma" holograph is in the same folder as the "Garden" poem. ${ }^{2}$ Whitman's errors in transcription clearly show that he was not copying out the four-stanza, sixteen-line "Brahma" from a printed source, but was recalling it from memory. He knew the poem well. Nevertheless, ampersands 